\title{
Naturalness in the production of vegetable oils and proteins ${ }^{\text {h }}$
}

\author{
Patrick Carré* \\ ITERG, 11, rue Gaspard Monge, 33600 Pessac, France
}

Received 24 July 2020 - Accepted 13 November 2020

\begin{abstract}
The crushing industry is called upon to modify its processing methods in response to a rising demand for vegetable proteins, while at the same time increasing transparency and naturality. Changing the processes without taking this request into account would mean risking rejection and failure. The social sciences have shown that the collective unconscious inextricably links the notion of naturalness to healthy eating, respect for the environment, and social honesty. However, this notion goes beyond what's rational and proves difficult to pin down when it comes to evaluating products. France does not recognize the ISO data sheet that defines what a "natural" ingredient is. Yet we do need a standard, if only to make informed choices between different possible technological paths. This standard of reference could be inspired by available norms in related fields, or it could be based on the best available technologies within a framework that takes into account both societal aspirations and the technical and economic possibilities of the industrial world. To achieve this, the sector's representative bodies, the State, and consumer advocate groups should engage in a collective approach.
\end{abstract}

Keywords: vegetable oils / proteins / naturalness / standards

Résumé - Naturalité dans la production d'huiles végétales et de protéines. L'industrie de la trituration se trouve confrontée à l'injonction de modifier ses modes de transformation pour mieux satisfaire l'appétit de protéines végétales quand dans le même temps, on exige d'elle plus de transparence, plus de naturalité. Changer ces procédés sans tenir compte de cette demande est un risque réel de rejet et d'échec. Les sciences sociales ont montré que la notion de naturalité agrège dans l'inconscient collectif les questions d'alimentation saine, de respect de l'environnement et d'honnêteté sociale. Mais cette notion échappe à la rationalité et s'avère difficile à cerner pour celui qui souhaite évaluer ses produits. La France ne reconnait pas la fiche technique que l'ISO a élaboré pour définir ce qu'est un ingrédient « naturel ». Nous avons pourtant besoin d'un référentiel, ne serait-ce que pour effectuer des choix rationnels entre différentes voies technologiques possibles. Ce référentiel peut s'inspirer d'autres référentiels disponibles dans des domaines voisins et pourrait s'appuyer sur la notion de meilleures technologies disponibles dans une démarche qui tendrait compte à la fois des aspirations de la société et des possibilité techniques et économiques du monde industriel. Pour cela, une démarche collective devrait entreprise entre les instances représentatives du secteur, l'état et les représentant des consommateurs.

Mots clés : huiles végétales / protéines / naturalité / normes

\section{Summary}

The crushing industry is faced with the injunction to modify its processing methods to better satisfy the appetite of vegetable proteins when, at the same time, it is asked for more transparency, more naturalness. Changing these processes without considering this demand is a real risk of rejection and failure. The social sciences have shown that the notion of naturalness aggregates in the collective unconscious the questions of healthy food, respect for the environment and social honesty. But this notion escapes rationality and proves difficult to define for those who wish to evaluate their products. France does not recognize the technical sheet that ISO has developed to define what is a "natural" ingredient. However, we need a benchmark, if only to make rational choices between different possible technological paths. This standard can be

\footnotetext{
Th Contribution to the Topical Issue "Technological challenges in oilseed crushing and refining / Défis technologiques de la trituration et du raffinage des oléagineux".

*Correspondence: p. carre@terresinovia.fr
} 
inspired by other standard available in neighboring fields and could be based on the notion of best available technologies in an approach that would take into account both the aspirations of society and the technical and economic possibilities of the industrial world. For this, a collective approach should be undertaken between the representative bodies of the sector, the state and consumers representatives.

\section{Introduction}

To ignore the demand for naturalness would be to risk a repeat of the GMO failure. It would also mean erring in a terrain where reason comes and goes with the wind.

At a time when France is about to unveil its new protein plan, when demand is becoming more qualitative, when society aspires to preserve the planet and consumers to rediscover naturalness in their diet, the crushing industry must review its technological model and economic positioning. Probably the most significant development in recent decades is increased longevity, which has changed our outlook on prioritizing short- and long-term problems (Angus and Westbrook, 2019). In a context of global warming and diminishing natural resources, populations have become more attentive to long-term issues. Countless television programs have detailed the food industry's supposedly harmful practices. Time and again we read magazine articles telling us about the less than desirable living conditions we are leaving to future generations. The current mindset is one of consumer guilt, and this guilt is exploited by marketing strategies that attribute qualities such as green, transparent, and various others to the high-tech products lining supermarket shelves (Eriksson and Machin, 2020). Admittedly, this trend is not without contradictions and is probably not universally distributed in a society where inequalities are growing and where a part of the population cares more about the end of the month than the end of the world (Foessel, 2018). Nonetheless, things are changing. Regulations are limiting the number of available pesticides and usable additives while industrial players are turning away from controversial technologies such as irradiation and reviewing their product composition under pressure from new players, like the mobile apps that rate products based on their ingredients (Ondet, 2018). The case of GMOs can be seen as emblematic of these technologies that are now constantly rejected. A fundamental reassessment is in order if we want to avoid embarking on an innovative path that diametrically opposes consumers' deepest expectations. This article will look at the nature of the demand for naturalness, and then examine the standards relating to it beyond the DGCCRF's somewhat dated note offering a definition for so-called "natural" products in the food industry. We will conclude by outlining possible answers that manufacturers in oils and oilseeds processing sector could provide.

\section{The nature of naturalness}

Drive it away, and it comes back twofold. Natural does not exist and yet the desire for it persists.

Naturality is a modern myth, a secular belief that we unconsciously subscribe to and rarely question. If natural means something unchanged by human intervention, then there is nothing natural in our food. Cereals have been domesticated for millennia, farming practices have improved over the centuries, and animals have been selected for breeding since the Neolithic period. Even wild game has evolved to adapt to the changing agricultural lands and fish caught in the farthest oceans are affected by pollution and the consequences of overfishing on ecosystems. In tackling this theme, we enter into quasi-religious territory armed with the weapons of reason, like Ulysses, oar on his shoulder, turning his back to the sea. Instead of scrutinizing the dogma, we'll try to pick up some general guidelines to orient our choices among those sulfur-smelling technologies.

The idea of naturalness might result from the multiple concerns the western middle class is confronted with. Erikson and Machin (previously cited) formulate a political reading of the situation. For them, our regulations - neo-liberal in inspiration - leave the market responsible for ensuring healthy, abundant, and accessible food. Competition is supposed to ensure a virtuous rivalry among companies by pushing them to constantly improve the quality of their products at the best prices. This would be tying up the dog of capitalism with a leash made of sausages. Despite the binding nature of regulations on labelling and consumer information, they leave marketing a lot of leeway to blur the meaning of nutritional information. For example, adding a few drops of ginger extract to a drink made of water and sugar is enough to make it a kind of natural elixir with invigorating properties. In response to this confusion, to the incoherence of rational discourse, naturalness is set up in opposition to human intervention, which is considered suspicious.

In a multidisciplinary review of the existing literature, Siipi (2013) concludes that in the consumer's mind, naturalness is deeply associated with healthy eating. In her study, naturalness covers four dimensions: (1) correspondence to nutritional needs, (2) satisfaction of needs in moderation, (3) authenticity, and (4) familiarity. The author states that communication needs to be clarified in order to avoid the risk of disappointing people's expectations. We'll see later that the authentic dimension, i.e. minimal human intervention, is the one most approaches rely on, but it perhaps misses part of the point. In a systematic review of the literature, retaining 72 studies conducted in 32 countries and involving more than 85000 consumers, Roman et al. (2017) showed that for the majority of consumers, naturalness is an omnipresent, crucial factor with 3 main components: the product's agricultural production method, processing method, and final properties. It should be noted that expectations regarding processing focus more specifically on minimal processing and its traditional nature. Consumers largely reject the principle of innovation and reproach virtual products such as cultured meat or foods produced by $3 \mathrm{D}$ printers for their lack of naturalness. The authors make gloomy predictions for products designed without taking naturalness into account.

Rozin et al. (2012), comparing how Europeans and North Americans accept the notion of naturalness, conclude that, overall, Western populations associate the idea of a "natural product" more with the absence of certain "negative" components (additives, pollution, human intervention) than with the presence of "positive" qualities. Genetically modified organisms are both commonly rejected and viewed differently on the two continents, with America being more moderate in 
its aversion. In this respect, the authors believe that this preference is based less on objective, qualitative characteristics than on idealistic notions. For example, a product that undergoes a first treatment to remove a substance and then a second treatment to restore that same substance would still be considered less natural than the initial product, despite having the same final composition. However, we can distinguish some processes that are less denaturing than others. Removing a substance is considered less denaturing than adding one.

The French Ministry of Agriculture commissioned a study on this quest for naturalness (Ministry of Agriculture, 2016) which sets out a number of precepts concerning processing methods. It recommends the use of gentler processes that preserve the products' inherent qualities and adhering to procedures for transparency and certification, while highlighting the steps, ingredients, and technological aids avoided. However, this study places the emphasis more on production methods for processed foodstuffs (GMO-free, pesticide-free, etc.) and the absence of chemical additives, than on the processes themselves.

The recent craze for new-generation plant-based burgers in the United States seems to contradict this trend (Vigdor, 2019). The technological choices made by Impossible Food (a USA based start-up) is based on the use of leghemoglobin, a protein similar to animal hemoglobin and responsible for the aspect and the taste of meat which is produced by a GM yeast: Pichia pastoris (Fraser et al., 2018). In addition, the burger patty is made of GM soy protein concentrates, themselves derived from hexane extraction, soy and coconut oils, and a list of 16 other ingredients including soy protein isolates (Moskin, 2019). This is the very opposite of naturalness as it has just been defined. In the United States, this boom in fake meat is seen as an avatar of high-tech success stories, and the high-tech food companies are often compared to Silicon Valley start-ups. But on closer inspection, the question of naturalness has not completely deserted the field of product design. Alongside Impossible Food, we find Beyond Meat (another start-up), which offers a recipe using non-GMO pea protein that specifically mentions the incorporation of pressed rapeseed oil, implying that hexane extraction was not used. It therefore seems that a middle road is opening up that is both technophile and environmentally friendly. It would allow us to offer substitutes to meat, which environmentalists say we should cut down on, without resorting to the most stronglycondemned technologies or abandoning the search for naturalness.

While the value of these simulated meats for health and the environment is questionable, the economic reality is that their development is a lesser evil than pursuing current consumption patterns. By the same token, its possible for the agri-food industry to make a positive contribution to sustainability through innovation, provided that it can balance consumers' expectations for naturalness, limiting its environmental impact, and maintaining economic competitiveness. In this article, after analyzing the concept of naturalness, we'll suggest some guidelines to differentiate processes according to their naturalness acceptability. Then, we'll assess the technologies currently used in crushing and try to imagine the processes which, in the future, will make it possible to offer ingredients that, although not natural, i.e. not unprocessed, can be produced using methods that denature as little as possible.

\section{Defining naturalness - What standard to use?}

\author{
Currently, there is no available standard for the French \\ food industry, but there are sources of inspiration from \\ other sectors.
}

It's not easy to define what a natural process is, but a lot of work has been invested in the attempt. An ISO text exists, but it is not a standard. It is a technical sheet (ISO/TS 19657:2017) that attempts to define what a natural ingredient is. It states that only physical, enzymatic, and microbiological processes are allowed and that these microbiological and enzymatic processes are admitted only if they do not deliberately produce substances that would not occur in nature. PH adjustments are allowed in these processes. Furthermore, should health safety or regulatory issues require further treatments, such treatments are acceptable only if they do not alter the ingredient's composition. France does not recognize this text. The relevant French services issued a note dating from 2009 (DGCCRF 2009-136) which gives a list of processes that preclude use of the term "natural", these include solvent extraction, ultrafiltration, electrodialysis, reverse osmosis, and ozonation. On the other hand, the processes of grinding, pressing, drying, and shelling are explicitly designated as not provoking any profound modification, and compatible with preserving naturalness. Thermal treatments such as freezing, pasteurization, cooking, roasting, and brewing are compatible, but the recommendation is to refer to "naturally sourced" ingredients rather than "natural" ingredients. This note leaves a lot of processes in a vacuum, with no real guidelines for classifying them. The DGCCRF (General Directorate for Competition Policy, Consumer Affairs and Fraud Control) is working on revising this note and is consulting the entities representing the various sectors of the agri-food industry regarding their needs. In the edible oils sector, the possibility of allowing physically refined oils to be presented as "oils of natural origin" has been mentioned. Since unitary refining operations are not listed among the mechanical transformation processes it permits, nor as processes that alter the essential characteristics of the product, the question has not yet been decided at the time of this writing.

The oldest standard relating to naturalness is the one on organic farming. Technically, organic farming products do not explicitly claim to be "natural", but in spirit, their method of production satisfies the main expectations for natural food. Historically, organic farming appeared almost at the same time as chemical fertilizers, i.e. in the aftermath of the First World War. It resulted from the convergence of several currents. The first was of a mystical nature, that is, Rudolf Steiner's biodynamics. A second was initiated by agronomist Albert Howard, who focused more on soil fertility and the importance of humus. Another current came from the medical field and focused on observing the connections between health and diet. A salient feature of this movement is that it challenged the simplistic approach adopted by conventional agronomists, which used the experimental method to study the consequences of inputs. It opposed a holistic approach that takes into account all the effects of the farmer's practices on the system, to the productivist reductionism of conventional agriculture. This trend has been growing significantly over the last years 
$(+109 \%$ of area certified organic in France from 2014 to 2019). It's development is based on two European regulations: the first (EC 834/2007) sets out the principles, and the second (889/2008), the practical ways and means for implementation. It should be noted that Article 6 of the first regulation lists several fairly simple principles regarding processing:

- Raw materials must be organically grown;

- Only essential additives can be used (specifically, when health safety is at risk);

- Misleading substances and methods are prohibited;

- Processing methods can be mechanical, biological or physical.

The processes must not adversely affect the environment, human health, plant health, nor animal health or welfare. GMOs are not authorized, nor are ionizing treatments. In relation to the vegetable oils and proteins sector, Regulation $889 / 2008$ establishes in Annex VIII.b the list of substances authorized for use in processing. These include citric acid, inert gases $\mathrm{N}_{2}, \mathrm{He}, \mathrm{Ar}, \mathrm{CO}_{2}$ ), lye (except for olives), ethanol as a solvent, activated carbons, and diatomaceous earth. This regulation only gives precise indications on the winemaking process, in which, for example, ultrafiltration is not permitted. It would allow for ethanol oil extraction in crushing as well as acid conditioning and alkaline neutralization in refining processes.

The FAO adopted a Brazilian classification system (NOVA), that puts foods into four categories according to their degree of processing (Monteiro et al., 2018). The four classes it defines are:

- Unprocessed or minimally processed products, which allows for drying, crushing, grinding, fractionating, filtering, roasting, boiling, non-alcoholic fermentation, pasteurization, refrigeration, freezing, placing in containers, and vacuum packaging.

- Culinary ingredients processed through pressing, refining, grinding, milling, and drying.

- Processed foods that generally result from mixing several ingredients using processes that are part of traditional cooking. No mention is made of treatments other than those mentioned above. The main criterion for classification is that the aim of processing must be only to improve the durability of the food and its sensory qualities.

- Highly processed foods are formulations made primarily of substances derived from foods but containing little or no Group 1 foods. The ingredients are generally not those found in traditional cooking. The technologies are not mentioned, but the ingredients listed are in general purely chemical compounds such as casein, lactose, and gluten or compounds resulting from secondary transformations such as enzymatic hydrolysis, interesterification, or hydrogenation.

The cosmetics industry, for its part, has established the ISO 16128 standard, which defines natural products. But, this standard only deals with a product's origin. It does not address chemical transformations, nor does it set any limits on processing. Unlike in the food sector, removing substances from a natural product does not cause it to lose its naturalness.
Contact with petroleum-based solvents is not prohibited. A synthetic molecule using, for example, a fatty acid that represents $50 \%$ of the molar mass of the final molecule, can be considered 50\% natural. Agents who are committed to more rigorous standards have condemned this norm and adopted the COSMOS standard that adapts the organic farming requirements to the cosmetics sector.

In the United States, the "Clean Label" program sets the bar. This label doesn't refer to a set norm, rather, it's an approach based mainly on the following principles: (1) Use fewer additives, (2) Use mostly traditional and recognizable ingredients to approximate home cooking recipes, (3) Avoid controversial ingredients such as GMO products, gluten, added sugars, colorings, etc., (4) Use production techniques that favor sustainable development, limit environmental impacts, and avoid controversial technologies. This approach is advertising conscious. It uses the term vitamin B1 over thiamine hydrochloride, for example, which is not possible in Europe where the regulations require additives to be designated by their chemical names. The Clean Label is not intended to guarantee naturalness, instead, it refers to the absence of contaminants or suspicious substances. Nonetheless, European agri-food companies have taken steps toward certification in order to target this market.

The COSMOS standard (COSMOS, 2019) sets itself apart in terms of processing by making clearer distinctions than the previously mentioned norms. In Annex 1, it lists just under 30 authorized physical processes. This list includes extraction, pressure, distillation, filtration, including UF and dialysis, crystallization, and ion exchange resins. The standard does not formally ban petroleum-derived solvents but limits their use to cases where no naturally occurring solvent is available. Given that, for lipids, it's possible to use ethanol or 2-methyloxolane, itself derived from the transformation of pentoses and recognized by Ecocert as suitable for the production of COSMOS ingredients, the use of hexane seems to be excluded. However, in order to use these solvents, there must be a way to recycle them and guarantee their elimination from finished products. The chemical transformation of ingredients is not excluded, but the permitted chemical engineering processes are limited to a positive list of fewer than 20, including esterification, transesterification, hydrogenation, hydrolysis, biotechnology processes, etc.

The Cosmos standard takes into account the fact that certain active ingredients and certain ingredients essential to product effectiveness cannot be obtained without a minimum of transformation. To this end, it clearly proscribes certain practices, but allows for a few exceptions when they are unavoidable or have little environmental impact, like phosphorylation of compounds for leave-in products. It lays down a number of principles such as respect for the naturallyoccurring, active substances present in ingredients, limiting waste, and minimizing water and energy consumption. And, it requires that the principles of green chemistry be respected (U.S. Environmental Protection Agency standard, 1998). In addition to the requirements already mentioned, this green chemistry standard imposes atom economy (yields of at least $50 \%$ ), low toxicity, high biodegradability, and minimal accident risks. As green chemistry is still young, the standard will provide fresh developments in the future. 




Fig. 1. proposed graph of product anthropization according to production itinerary. The vertical bars are meant to represent the extent of denaturation. The heights shown here are arbitrary and given for information purposes only.

\section{Towards an open and evolutionary approach}

There is an EU Directive (2010/75) that addressed how industry should control environmental risks and introduces the notion of best available technology. It organizes information sharing between manufacturers in each sector and nongovernmental organizations working to protect the environment. The goal of these encounters is to identify the best techniques available for each type of production in light of sustainable development's multiple requirements. This approach makes it possible to factor in both the technical performance and economic feasibility of each process. Its character is limiting, because it aims to reduce pollution and the risk of accidents. Otherwise, the most ethical companies would be penalized in comparison with the most polluting. The Best available technologies are listed in documents called "BREFs" for "Best available techniques REFerence documents". The directive provides for these documents to be revised regularly to keep up with developments in knowledge and technology (Article 19).

It might be possible to adopt this notion of best available techniques mutatis mutandis, in relation to naturalness. A debate could be organized for each type of production in order to identify the most acceptable processes, with a view to reconciling the economically possible with the sociologically desirable. The aim would be to establish a scale of artificiality and determine which processes denature the least. A protostandard could be established. This would concur with the principles in the COSMOS standard that recognizes both the ideal of minimal processing and the industry's very real need for functional ingredients with characteristics that need to be preserved. We have seen in the case of fake meats that it appears possible to produce similar products through very different approaches.
This approach should take the ingredient's full technical itinerary into account. It might also consider criteria like the ones listed below:

- Numerical minimization of unit operations;

- Familiarity/tradition;

- Technical robustness;

- Intensity of the ingredient's substance modification: native, purified, denatured, substantially modified;

- Controversial processes (e.g. use of hexane, genetically modified microorganisms, etc.).

On the other hand, we don't feel that the physical versus chemical process dichotomy is sufficiently well-founded to be considered. For example, heating is classified as a physical treatment but is likely to cause chemical reactions such as the Maillard reaction, whereas hexane extraction is classified as a chemical process but leaves the molecules it separates in their original state. We must note that hexane is undesirable, while cooking is accepted as a traditional and familiar process. The rules of naturalness are like French spelling rules, composed of regularities interspersed with exceptions, aberrations, and a legacy from the past. And violating them touches upon identity.

We could adopt a graphical representation of the itineraries that describes, for each step, the possibility of degradation in proportion to the denaturation operated, in order to compare the ingredients obtained by each processes Figure 1 illustrates this idea, comparing two refined oils produced through processes with different levels of naturalness. In this example, the loss of naturalness illustrated by the height of the vertical lines is purely indicative. In order to obtain representative values, we would have to collect a sufficient number of reviews in a context that allows us to compare the processes and take their variations into account. For example, in the deodorization step, temperature conditions can range from 160 to $250^{\circ} \mathrm{C}$, 
residence times from 1 to $4 \mathrm{~h}$, and pressures from just under 1 millibar to 4 millibars. These variables can have a significant effect on the level of micronutrient loss and engender newlyformed undesirable molecules.

This subjective approach is somewhat akin to an aesthetic judgement, which is not without its difficulties. Subjectivity can change over time and in this domain, the notion of truth has little meaning.

\section{Outstanding issues}

The approach to assessing naturalness that we are proposing must be part of a broader reflection and not be in systematic opposition to any technological progress. We must be wary of this shortcoming because it could push us toward abandoning R\&D efforts at a time when the need to invent more sustainable production and processing methods has never been more pressing. In parallel, we have to recognized that sometimes it's best to "leave well enough alone" and that the need for innovation isn't the same in all sectors of activity. In the crushing industry, it is clear that progress is much more in demand in relation to proteins than to oils. Reducing meatproduct consumption will have a much greater ecological impact than many of the other actions we can take (Hallström et al., 2015). Broadening the range of vegetable proteins, even at the cost of greater artificiality, is the kind of compromise that consumers will be more inclined to accept than one involving products that have available and accessible "natural" variants. Once again, the example of plant-based burgers shows that it is possible to offer solutions that are more elegant than others. While multiple constraints can sometimes inhibit innovation, they can also stimulate imagination. Taking the demand for naturalness into account also gives greater meaning to manufacturer's actions - from their design teams to their sales force. This approach has a moral dimension in that it allows companies to base their claims of naturalness on a foundation of sincerity and honesty, if they show that they are using the best available techniques.

\section{References}

Angus A, Westbrook G. 2019. Top 10 Global Consumer Trends. London, UK: Euromonitor International.

Commission Regulation EC 889/2008. 2008. Modified Commission Regulation EC 889/2008 of September 5, 2008 laying down detailed rules for the application of Council Regulation EC 834/ 2007 on organic production and labeling of organic products with regard to organic production, labeling and controls.

Cosmos-Version 3. 2019. https://cosmosstandard.files.wordpress. com/2019/04/fr_cosmos-standard-v3.0.pdf (consulté le 28 mars 2020).
Council Regulation 834/2007. 2007. Council Regulation 834/2007 of 28 June 2007 on organic production and labeling of organic products and repealing Regulation (EEC) No 2092/91.

DGCCRF. 2009. Emploi des termes «naturel », «100\% nature» et de toute autre expression équivalente sur l'étiquetage des denrées alimentaires - Note d'information 2009.136.

EPA-US Environment Protection Agency. 1998. www.epa.gov/ greenchemistry.

Eriksson G, Machin D. 2020. Discourses of "Good Food": The commercialization of healthy and ethical eating. Discourse Context Media 33: 100365.

European Directive 2010/75/EU. 2010. European Directive 2010/75/ EU of the European Parliament and of the Council of 24 November 2010 relating to industrial emissions.

Fraser RZ, Shitut M, Agrawal P, Mendes O, Klapholz S. 2018. Safety evaluation of soy leghemoglobin prote in preparation derived from Pichia pastoris, intended for use as a flavor catalyst in plantbased meat. Int J Toxicol 37(3): 241-262.

Foessel M. 2018. «Chaque fin de mois, la fin du monde», Libération [en ligne] Available from https://www.liberation.fr/debats/2018/ 12/06/chaque-fin-de-mois-la-fin-du-monde_1696440 (consulté le 12 janvier 2019).

Hallström E, Carlsson-Kanyama A, Börjesson P. 2015. Environmental impact of dietary change: a systematic review. J Clean Prod 91: $1-11$.

ISO/TS 19657. 2017. (E.) Definitions and technical criteria for food ingredients to be considered as natural.

Ministère de l'Agriculture. 2016. Recherche de naturalité- Etude commandée dans le cadre du Contrat de Filière Agroalimentaire (Action $\mathrm{N}^{\mathrm{o}} 36$ ) par le ministère de l'Agriculture, de l'Agroalimentaire et de la Forêt, l'ANIA, la CGAD, la CGI, Coop de France, la FCD et FranceAgriMer (consulté en mars 2020).

Monteiro CA, Cannon G, Moubarac JC, Levy RB, Louzada MLC, Jaime PC. 2018. The UN Decade of Nutrition, the NOVA food classification and the trouble with ultra-processing. Public Health Nutr 21(1): 5-17.

Moskin J. 2019. How do the new plant-based burgers stack up? We taste-tested them. The New-York Times. https://www.nytimes. com/2019/10/22/dining/veggie-burger-taste-test.html.

Ondet G. 2018. Les meilleures applications gratuites pour savoir ce que vous mangez. O1net. https://www.01net.com/astuces/lesmeilleures-applications-gratuites-pour-savoir-ce-que-vous-man gez-1384494.html (consulté le 4 février 2020).

Roman S, Sánchez-Siles LM, Siegrist M. 2017. The importance of food naturalness for consumers: Results of a systematic review. Trends Food Sci Technol 67: 44-57.

Rozin P, Fischler C, Shields-Argelès C. 2012. European and American perspectives on the meaning of natural. Appetite 59 (2): 448-455.

Siipi H. 2013. Is natural food healthy? J Agric Environ Ethics 26(4): 797-812.

Vigdor. 2019. Meatless burger near impossible to find. The New-York Times, p. 20

Cite this article as: Carré P. 2021. Naturalness in the production of vegetable oils and proteins. OCL 28: 10. 